\title{
The 'allurements of the European presence': Examining explanations of Wongatha behaviour in the northern Goldfields of Western Australia
}

\author{
Craig Muller
}

In the early summer of 1930, Peter Elkin, a prominent figure in early Australian anthropology, travelled to the Mount Margaret Mission, near Laverton in the northern Goldfields region of Western Australia. He did so to follow up research begun on the eastern edge of the Nullarbor Plain, with Aboriginal groups who comprised what was later dubbed the Western Desert Cultural Bloc, a common cultural region covering the vast arid zone of central Australia. Elkin conducted fieldwork at Mount Margaret for three weeks, met only some of the Aboriginal people there and never returned, but in an article published subsequently he made a significant extrapolation. The Aboriginal people at Mount Margaret did not belong there. They had come in from the Warburton Range and the border country and replaced the local groups which had, as Elkin phrased it, 'almost ceased to exist'. ${ }^{1}$

Sporadic further anthropological fieldwork was conducted in the area during the seven decades following Elkin's research, but the information found was confined to specialist publications. No effort was made to construct a historical narrative of the Aboriginal people in this part of the Western Desert until native title in the late 1990s sparked a research effort that rediscovered what had become ethnographic arcana, with significant consequences. At this time, the Wongatha people claimed natie title rights over their country, a large area extending eastwards from the area around Mount Margaret. In opposing the claim, the respondents, led by the Western Australian state government, the Commonwealth and the Western Australian Pastoralists and Graziers Association, put Elkin's statement at the forefront of their argument that the Wongatha were descended from a migrating people and therefore did not have long term attachment to the area they were claiming. ${ }^{2}$ This effort was effective: on 5 February 2007, the Federal Court dismissed the claim, citing Elkin as a

1 Elkin 1943: 25, quoted in Federal Court of Australia 2007: para 579.

2 Federal Court of Australia 2007: para 580. 
crucial source underpinning the decision. ${ }^{3}$ In summarising, Lindgren J. said that migration or population shift into the claim area, as Elkin had argued, was 'a distinguishing feature of the present case ... well established ... not disputed' ${ }^{4}$

Research for the Wongatha native title claim followed the heuristic principle that privileges early ethnographic material over other sources (as often happens with native title claims elsewhere), ${ }^{5}$ even though such material was not subject to detailed historiographical critique. ${ }^{6}$ Limiting the range and analysis of available historical sources risks limiting outcomes; in this case, alternative sources suggest Elkin was mistaken. A fuller accounting of the sources shows that Elkin's research methodologies at Mount Margaret were deeply flawed, while his statements about Aboriginal people were flatly contradicted by other wellplaced commentators, among them the mission's founder and 30-year resident, the Swiss-born evangelist Rudolph (Rod) Schenk.

Ethnographic and historical research - especially, but certainly not only, for native title - imposes definitions of Aboriginal identity. ${ }^{7}$ To the end of 2011, there had been 175 native title determinations with a further 443 claimant applications outstanding. ${ }^{8}$ Almost all of these 600 claims would have been accompanied by at least two expert reports and in some cases half a dozen or more, most by anthropologists. These reports variously support or refute Aboriginal assertions of identity. Offering guidance to the system, Justice Mansfield noted,

anthropological evidence may provide a framework for understanding the primary evidence of Aboriginal witnesses [giving native title evidence] in respect of the acknowledgement and observance of traditional laws, customs and practices. ${ }^{9}$

But the basis of historical anthropological evidence, too, needs to be assessed.

Elkin was a strong proponent of assimilation, arguing that it was necessary for Aboriginal people to move to the superior society in order to survive. ${ }^{10}$ This shaped his thinking. He wrote from Ooldea in South Australia that he learned that Aborigines from the south-eastern parts of Western Australia were 'probably' migrating westward towards Laverton and Mount Margaret. ${ }^{11}$ Going to that area he says he 'found that my inferences were correct' ${ }^{12}$ He was also already convinced that Aborigines on the fringes of European settlement would die out, their place to be taken by others from deeper in the desert and he found this to

3 Federal Court of Australia 2007: para 701.

4 Federal Court of Australia 2007: para 301.

5 See, for example, Pitty 1999 and Reilly 2000 for discussion of how this occurred in the Yorta Yorta people's native title claim.

6 An alternative case was made, including by this author, but patently not well enough; material contradicting Elkin was presented but had little discernible impact.

7 See, for example, Morton 1998; Tonkinson 1999; Merlan 2006: 193; Dauth 2011.

8 National Native Title Tribunal 2012.

9 Federal Court of Australia 2004: para 89.

10 McGregor nd.

11 Elkin 1931-32: 48.

12 Elkin 1931-32: 48. 
be correct too. ${ }^{13}$ According to Elkin, life in proximity to European settlements offered Western Desert Aborigines 'comparative attractiveness', ${ }^{14}$ a sentiment echoed in the Federal Court 70 years later: 'By succumbing to the allurements of the European presence, the claimants' ancestors changed the legal landscape for today's native title purposes.' ${ }^{\prime 15}$

The Court told the Wongatha people their ancestors had moved off their traditional lands to inquilinate in the northern Goldfields where they did not belong. The dying out of the Aboriginal people who occupied the northern Goldfields at the time of European settlement and replacement migration from the desert became findings of fact in the Court and the identity of applicants was branded. Future dealings between the Wongatha and government would proceed within a framework imposed by these findings.

Considerable Aboriginal movement did occur in the northern Goldfields region but these patterns of behaviour have often been described through particular cultural lenses. In this case, the concept of migration became the metaphor that allowed non-Aboriginal commentators to comprehend Aboriginal activities in the northern Goldfields.

At Mount Margaret, Elkin recorded meeting approximately 200 Aborigines. All bar one had come in from country far beyond the frontier; Mandjindja from the Warburton Range and Mula, Wongaii and Ngalia from the desert well to the east and south-east of the mission. ${ }^{16}$ This mass movement had been made possible because the original Mount Margaret-area population had died out. ${ }^{17}$

Yet, based on census figures supplied by local police officers, in their role as Protectors of Aborigines, there were 1,319 Aboriginal people in the Laverton district (an area that included Mount Margaret) the year Elkin visited and 1,255 the following year. ${ }^{18}$ Even allowing for expected difficulties in contacting seminomadic people it is still notable that Elkin failed to account for 85 per cent of the area's Aboriginal people.

Elkin also missed the plentiful evidence of a local Aboriginal population that had been in long-term contact with European settlers. Some two-dozen children had

13 Elkin 1931-32: 49.

14 Elkin 1931-32: 46.

15 Federal Court of Australia 2007: 3.

16 Elkin 1931-32: 49. Elkin's field notes describing the groups at Mount Margaret are brief but vary slightly from the published findings. Here, he recorded a 'Laverton mob' whose members had come from Mandjindja country, a Linden mob from the country to the south as well as Kogara, Yalindjara and Kaiili people. See Elkin, AP 1930,'notebook 8', Acc 664, item 1/2/ 138, University of Sydney. Half a century later, Elkin recalled the Aboriginal population at Mount Margaret in 1930 as consisting of "the remaining "local" Aborigines together with large numbers who were then moving in from the Warburton Ranges and thereabouts'. Elkin 1980. The inverted commas around local are intriguing.

17 Elkin 1931-32: 48.

18 Western Australia, Chief Protector of Aborigines, Annual Report..., 1930: 28, 1931: 27. 
been born at Mount Margaret during the 1920s. Many were resident when Elkin visited. A. O. Neville, then Chief Protector of Aborigines, wrote approvingly in 1931,

That civilising influences are at work is evident from the number of requests received to permit legal marriages to take place with full Christian rites in place of the usual native customs. ${ }^{19}$

The certificates from these marriages show some of the people who were born in the district between about 1905 and the 1920s. Schenk reckoned by the mid1930s there were 50 people of mixed descent in the Laverton district, half of them resident at Mount Margaret. ${ }^{20}$

Observing that very few of the Aborigines at Mount Margaret spoke or understood any English ${ }^{21}$ fits Elkin's claim as to their places of origin but is starkly at odds with the known mission population profile. In the first year of operations, 1921-22, Rod and his wife Mysie, concluding that 'the Wongutha [sic] needed a good grasp of English', ${ }^{22}$ made the decision to teach in that language. At the end of 1923, they announced triumphantly, 'There seemed to be a sudden spurt on English comprehension' ${ }^{23}$

At a minimum, several mission-associated Wongatha were explicitly acknowledged as multilingual. Sometime employee Kunjil understood the English spoken to him as early as 1923, while it was noted in 1930 that both Jim Cookadoo alias Jim Barnes and Snowy Barnes were fluent in English. ${ }^{24}$ Ranji McIntyre, probably born in 1908, had learned to speak English from a prospector before his arrival at the mission, at the age of about 13 or 14. Other Wongatha youths, such as Bert Thomas and Steve Earle, arrived in the mission's early years and stayed. If they were not already fluent they must have learned English working closely with the Schenks and others over the ensuing years. There was no choice for Aboriginal mission inmates; Rod Schenk never learned Wongatha. ${ }^{25}$ Language aside, Elkin's apparent obliviousness to the long-term presence of Aboriginal people seems to have extended to the substantial buildings at Mount Margaret - including dormitories built for a population he thought had spent almost no time with Europeans.

It remains a puzzle how Elkin failed to acknowledge the bulk of the district's Aboriginal population. Perhaps Schenk tried to keep the mission inmates away, yet it seems Elkin did make contact with at least some of the long-term residents. Subsequent to his visit, the missionaries accused Elkin of 'using our Christian men... There were corroborees enacted then that they had not seen for years,

19 Western Australia, Chief Protector of Aborigines, Annual Report..., 1931: 23.

20 Schenk 1935.

21 Morgan 1985: 49.

22 Morgan 1985: 61.

23 Morgan 1985: 73, 69.

24 Morgan 1985: 12, 117.

25 Morgan 1985: 61. 
the men said' ${ }^{26}$ It is impossible to reconcile the notions that all of those Elkin spoke to were from the distant east and did not speak English and that he 'used' Christian converts - men who were resident at Mount Margaret, who had received their Christian instruction in English and who had been so long under the missionaries' influence they had ceased to participate in the Law.

It may be that in setting out to make inquiries 'into the social organization, totemism and customs of the natives' ${ }^{27}$ Elkin omitted part-Aboriginal people from his research, but this possibility presents at least two concerns. Firstly, how did he determine, in three weeks, who among the several hundred people at Mount Margaret was part-Aboriginal? How could he (and those citing him) be sure he got this right? Secondly, if he did ignore part-Aboriginal people his reasoning must have been that they were too assimilated and therefore had lost their culture, a dubious point from which to advance.

To demonstrate whether Elkin's model of migration and population replacement occurred several questions have to be addressed: what else is said about the original Aboriginal populations of Mount Margaret and Laverton; did people come in; if so, were they attracted by European influences or were other, traditional behaviours occurring; and were people transferring across cultural zones to the extent the movement must be called migration rather than normal hunter-gatherer movement? Considerable data, alternative to Elkin's, exists that can be interrogated for answers.

Firstly, if the Wongatha population decreased significantly in the first decades of European settlement, as Elkin had it, there should be evidence in the historic record of epidemic disease, massacres or outward migration. Explorer David Carnegie specifically refuted suggestions that massacres of Aboriginal people took place in the region..$^{28}$ However, survivors of gunshot wounds were said to be present in the northern Goldfields in the early settlement period. ${ }^{29}$ These reports were not investigated and it is not known whether the incidents in which the wounds occurred were widespread and whether other people were killed, though this must be considered a strong possibility. One mass killing was widely reported during the early contact period - at Mount Catherine late in 1894, where at least two and possibly considerably more Aborigines were shot. ${ }^{30} \mathrm{On}$ another occasion, an Aboriginal person reported a massacre having occurred near Mount Margaret, ${ }^{31}$ an incident that was investigated but considered

26 Morgan 1985: 121.

27 Elkin 1931-32: 46.

28 Carnegie 1982: 34-35.

29 Mount Leonora Miner, 8 March 1902.

30 Accounts vary considerably. An eyewitness who was later discredited claimed an entire group was put to death, while another European who spoke to survivors put the number at two (West Australian, 12 February 1895: 5 and McDonald, MN1124, Acc 3406A, item1, Battye Library). Aboriginal people today recount a widespread oral history of the Mount Catherine massacre in which all but one or two of a group trapped in a rock canyon were killed.

31 Stokes, Report, 2 October 1895, Con 430, file 2199/1895, SROWA. 
unfounded. After late 1896, there was a police presence at Laverton, Leonora and Menzies, inspection of Aboriginal people by Aborigines Department employees, newspapers and a sizable European population and it becomes much less likely that unreported wholesale murders occurred. It cannot be said how many Aboriginal people died during the frontier violence that occurred in the region but nothing suggests that the number approached a level that would threaten population viability.

It is known that exposure to introduced diseases for which Aboriginal people had no resistance accounted for many deaths in advance of and after European settlement. This occurred in the northern Goldfields, though the sparseness of the population and the arid conditions seem to have been alleviating factors. Richard Helms, the naturalist with the Elder Expedition crossing near the eastern extent of Wongatha country a year before the Coolgardie gold rush, reported finding no signs of disease among the Aboriginal people he met. ${ }^{32}$ While hunger, even famine, was a regular feature for Aboriginal people after European settlement, specific reports for the Laverton, Menzies and Kookynie districts between 1901 and 1905 said the local Aborigines were healthy. ${ }^{33}$ These reports were made by government employees who were diligent in reporting evidence of diseases because of the fear of transmission to the European population. A report from Duketon did suggest Aboriginal people there were afflicted with contagious diseases, with one death reported in 1906. ${ }^{34}$ There is otherwise no support for the notion that disease killed many northern Goldfields Aborigines.

Norman Tindale, Elkin's contemporary, speculated on an outward migration of Aboriginal people from the northern Goldfields to Kalgoorlie, ${ }^{35}$ but the available information indicates otherwise. Such mass migration would have been reported, if not at the point of exodus then by newspapers and other sources who invariably commented when Aboriginal people appeared at their location. In 1908, the Kalgoorlie District Police Office submitted that there were approximately 70 Aboriginal people in the larger Kalgoorlie area. ${ }^{36}$ The collated police reports from Kalgoorlie and nearby Coolgardie from 1912 show that there were no Aborigines living permanently in the area, though people passed through periodically. ${ }^{37}$ In 1915 , when the population was declining rather than increasing, there were just 13 Aboriginal people known to be living in the Kalgoorlie district. ${ }^{38}$

Statements about Aboriginal attachment to country also discredit the migration theory. In 1901, Chief Protector of Aborigines Henry Prinsep visited Kalgoorlie

32 Helms 1896: 242.

33 Olivey, Western Australia, Aborigines Department, Report..., 1902: 24; Dunkley, Arthur, Report dated 22 December 1902, Con 255, file 40/1903, Report dated 19 December 1903, Con 255, file 29/1904, SROWA; Beurteaux, ECD, Report, 28 May 1906, Con 255, file 423/1906, SROWA.

34 Burt, AE, Report, 15 September 1904, Con 255, file 375/1904, SROWA; Beurteaux, ECD, Report, 28 May 1906, Con 255, file 423/1906, SROWA.

35 Tindale 1974: 252, 258.

36 Western Australia, Aborigines Department, Report..., 1908: 14-15.

37 Western Australia, Aborigines Department, Report..., 1910: 19.

38 Western Australia, Aborigines Department, Report..., 1915: 27. 
to discuss civic concerns about Aboriginal people loitering and begging. ${ }^{39} \mathrm{He}$ included a meeting with some of the local Aboriginal elders, who suggested that if a reserve be created for Aboriginal people to live on, as was being proposed, their preference was for the south coast, suggesting they were from this direction..$^{40}$ Conversely, both Kalgoorlie and Laverton police agreed that northern Goldfields Aborigines were unwilling to cross the territorial boundary at approximately Menzies ${ }^{41}$ except temporarily to attend ceremonies. ${ }^{42}$

In addition to the lack of evidence of population demise, a miscellany of sources provides a continuous record of a group of Aborigines being present in the northern Goldfields from the time of first European contact. Even before permanent settlement, the explorers John Forrest and Lindsay Wells encountered Aboriginal people in the region, in 1869 and 1892 respectively. ${ }^{43}$ From the end of 1896, Police Constable Glass began patrolling northward from his base at Niagara to the newly established gold-mining centres that sprang up north and west of Lake Carey. Glass found a few Aborigines camped at Malcolm in November 1896, more substantial camps of 30 people at Bummers Creek and 50 at Pindinni Soak in February 1897, a much larger gathering of about 100 at Mount Margaret the following month, and about 40 people were at Cutmore's Well in May 1897..

Glass's successors found this pattern continued. Members of the 'Mount Weld tribe' were camped at nearby Mount Margaret in July 1898, ${ }^{45}$ another camp was set up at Hawks Nest, between Laverton and Mount Margaret in August $1898^{46}$ and a third at Laverton in November $1899 .{ }^{47}$ Just before the last Christmas of the century, about 30 Aborigines from the Erlistoun district were seen at Morgans en route to Menzies. ${ }^{48}$ In April 1900, Corporal Feely estimated the Aboriginal population on the Mount Margaret Goldfield to be approximately 300 occasional visitors to the townships. ${ }^{49}$ Eight years later, his colleague O'Connor made a submission during the brief time a police station was operating at Yundamindera, south of Laverton, noting there was a resident Aboriginal population in the area, ${ }^{50}$ while the same was the case for the Linden district in February $1909 .{ }^{51}$

39 Western Australia, Aborigines Department, Report..., 1901: 6-7.

40 Western Australia, Aborigines Department, Report..., 1901: 6-7.

41 Western Australia, Aborigines Department, Report..., 1908: 14-15; Gravestock, J, Report dated 2 August 1938, Con 993, file 691/1938, SROWA.

42 See, for example, Bailey, CA, Report dated 10 October 1896, Con 495, item 45,, Report dated 14 February 1897, Con 495, item 47, SROWA; Coolgardie Miner, 30 October 1896 and 4 December 1896.

43 Forrest 1969: 49-50; Wells 1893: 64-67.

44 Glass, J, Report dated 29 November 1896, Con 430, file 4119/1896, Reports dated 11 and 22 February 1897, Con 430, file 849/1897, Report dated 24 March 1897, Con 430, file 1557/1897, Report dated 21 May 1897, Con 430, file 1557/1897, SROWA.

45 Report dated 15 July 1898, Con 431, item 1, SROWA.

46 Report dated 15 August 1898, Con 431, item 1, SROWA.

47 Report dated 25 November 1899, Con 431, item 1, SROWA.

48 Sullivan, Report dated 24 December 1900, Con 431, item 5209/1900, SROWA.

49 Feely, W, Report dated 1 April 1900, Con 255, file 172/1900, SROWA.

50 O'Connor, J, Report dated 30 June 1908, Con 255, file 712/1908, SROWA.

51 Stewart, R, Letter dated 23 February 1909, Con 652, file 160/1909, SROWA. 
The small newspapers that briefly flourished in the Goldfields in the decade from the late 1890s trace the local Aboriginal population during the first decade of European settlement. Members of 'the tribe' - by which we must presume local - were visiting Laverton in $1899,{ }^{52}$ while three years later the Laverton Mercury identified a group which had been in the Mount Margaret area since first European settlement. ${ }^{53}$ Acknowledgments of the local origins of the Aboriginal people in the Laverton district was repeated throughout 1903, with the Laverton Mercury referring to the 'aboriginals of these parts', 'the black population of the Margaret district' and 'the blacks in this neighbourhood' ${ }^{54}$

At Mertondale in 1902 it was noted, 'some time ago a number of blacks made their presence objectionable by loafing around the town for several days' ${ }^{55}$ This pattern continued: in 1904, 'blacks ... have made their presence around Malcolm particularly objectionable during their recent visit' ${ }^{56}$ in the same place the next year, 'The blacks paid another visit to town during the week', ${ }^{57}$ the settlers at Morgans were being 'much troubled' by Aboriginal people appearing at the town in 1905. ${ }^{58}$ Numerous other reports describe Aboriginal movements as 'visits' to the various towns, ${ }^{59}$ while various newspaper articles note the Aboriginal camps that were set up at various times. ${ }^{60}$ These towns were inside the frontier and therefore not the expected places of first contact for people coming in from the desert. Rather, these records show a transient northern Goldfields population.

Reports from the Aborigines Department, often giving rough census details and descriptions of Aborigines' physical conditions, provide a third set of source material. Travelling Inspector C. A. Bailey, sent to report in 1896, counted some 150 Aborigines he said belonged to the Menzies and Mount Margaret district. ${ }^{61}$ An Aboriginal population of 45 was reported for the Niagara district early in $1899,{ }^{62}$ while Bailey's successor, G. S. Olivey, encountered 'a big mob of natives' at Laverton who had been in the area for some time, 20 Aborigines at Morgans, another 20 at Kookynie and a handful more at Niagara. ${ }^{63}$ A group described as the 'Laverton tribe' was present in 1908. ${ }^{64}$ The number of Wongatha residing in the northern Goldfields was considered sufficiently large that in 1903 Chief Protector of Aborigines Henry Prinsep proposed setting aside a reserve at or

\footnotetext{
52 Laverton Mercury, 4 November 1899.

53 Laverton Mercury, 22 and 23 November 1902.

54 Laverton Mercury, 4 July and 18 December 1903.

55 Malcolm Chronicle and Leonora Advertiser, 23 May 1902.

56 Malcolm Chronicle and Leonora Advertiser, 10 June 1904.

57 Malcolm Chronicle and Leonora Advertiser, 20 January 1905.

58 Laverton Mercury, 14 July 1905.

59 See, for examples, The Mount Leonora Miner, 8 March 1902, 15 August 1903 and 2 August 1905; Laverton Mercury, 7 December 1907; and Malcolm Chronicle and Leonora Advertiser, 27 November 1903 and 10 June 1904.

60 Malcolm Chronicle and Leonora Advertiser, 28 April 1900, 14 December 1901, 15 November 1902 and 1 January 1904.

61 Bailey, CA, Report dated 10 October 1896, Con 495, item 45, SROWA.

62 Report dated 22 February 1899, Con 255, file 145/1899, SROWA.

63 Western Australia, Aborigines Department, Report..., 1902: 24.

64 Aborigines Department 1908: 15.
} 
near Morgans, an idea that had the Laverton Mercury declaring derisively that this would only be giving 'what already belongs to them' ${ }^{65}$ strongly hinting at their localness.

In 1917, Laverton Constable O'Loughlin wrote that he occasionally issued rations to a number of elderly Aborigines who had lived in the Laverton district for years. ${ }^{66}$ In the mid-1920s, a colleague at Morgans, S. E. Perks, reported on the 'local natives', ${ }^{67}$ while the minister of the Aborigines Department enquired into the possibility of shifting 'the local tribes' from the Mount Margaret district in 1930. ${ }^{68} \mathrm{~A}$ mid-1930s report noted the presence of 16 people who 'belong to Menzies' ${ }^{69}$ There is no obvious discontinuity in this litany; no point where it can be shown there was major population demise or replacement.

Confirmation of population continuity comes from the two European men whose long tenure in the northern Goldfields and regular dealings with Aboriginal people gave them far more participation/observation experience than Elkin had. Constable E. P. Thompson was issuing rations at Laverton in 1921 to Aboriginal people most of whom, he reported, were born and grew up locally and who for that reason would not allow him to hunt them away as he had been ordered.$^{70}$ Most of the ration recipients would have been elderly, since it was a strict Aborigines Department instruction for many years that only people who could not work or hunt be allowed to receive rations. ${ }^{71}$ Age and health details on ration lists show this policy was put into practice. It must therefore have been the case that Thompson was including in his description many who had been born in the area prior to European settlement, less than 30 years earlier.

The Mount Margaret Mission in its infancy hosted Aborigines who referred to themselves as 'Margaret blackfellas', while others identified with Laverton. ${ }^{72}$ In 1934, when Schenk gave evidence before the Moseley Royal Commission into Aboriginal welfare, he could identify more than 200 Aborigines who had been born and grew up in the district. ${ }^{73}$ It is nigh impossible to doubt the verisimilitude of the reports these two men submitted, Thompson to his superiors explaining why it was difficult to follow orders and Schenk to a Royal Commission.

65 Laverton Mercury, 16 April 1903

66 O'Loughlin, Letter dated 18 July 1917, Con 993, file 19/1927, SROWA.

67 Perks, SE, Report dated 1 August 1924, Con 993, file 19/1927, SROWA. A few months later, Perks stated there were 150 Aboriginal people in the Morgans district and that they were kept out of the towns (see Perks, Report dated 19 December 1924, Con 993, file 19/1927, SROWA).

68 Kitson, WH, Report dated 17 March 1930, Con 993, file 431/1928, SROWA.

69 Letter dated 25 May 1936, Con 993, file 195/1936, SROWA.

70 Thompson, Letter dated 11 April 1921, Con 3354, item 1: 226, SROWA.

71 This order was made repeatedly: firstly, in the Goldfields context, in 1897 and 1898 (Bailey, CA, Report dated 14 February 1897, Con 495, item 47: 9, SROWA and Haebich 1992: 55); reaffirmed by the Chief Protector of Aborigines in 1908 (Western Australia, Aborigines Department, Report..., 1908: 15) and 1911 (Gale, CF in Con 652, file 479A/1911); and again by the new Chief Protector in 1915 (Neville, Letter dated 25 February 1915, Con 993, file 369/1926, SROWA).

72 Schenk 1923a, b.

73 'Statement by Mr. R.S. Schenk', 1934, Con 987, item S, SROWA. By the time of the Royal Commission Schenk had spent 13 years in intimate contact with Aboriginal people at Mount Margaret and had been told by them that they were local to the area. In 1953, when Schenk again 
Schenk had learned these people called themselves Wongutha, that they were the same group that had been in the area when settlers arrived in 1894 and that they regarded the Mount Margaret area as their country. ${ }^{74}$ This proposition can be tested: attachment to country, including whether people claim the right to say who can come on it, can be measured, to an extent, in what people say and how they behave (usually as seen through the lens of non-Aboriginal observers). A migrant group would not, wholesale, develop such attachments and rights through short term association - Aboriginal identity is vested in areas of country and not subject to rapid change.

Describing the Goldfields after a decade of European presence, Chief Protector of Aborigines Henry Prinsep complained in 1905 that the continued strength of Aboriginal feeling for country placed a strain on his department's budget:

Each little tribe of natives so loves its own little district, and this love has been inherent in these races for such a long period that the old and crippled members of the tribe will hardly ever seek relief out of their district. They will die first; and to prevent such a wholesale cruelty, I see no way but to continue nearly all these relieving stations [at various Goldfields towns]. ${ }^{75}$

These lines demolish the argument that Aborigines had migrated in during the preceding ten years, driven by a desire to cadge European foods, with little regard to their country of origin. Instead, the proscription on staying in the right territory was ironclad, even at the risk of starvation.

David McDonald, a close and long-term observer of Aboriginal people from the time of his arrival at Murrin Murrin in the 1890s, agreed. He remembered that 'Wongi ... was the name of the native tribe who roamed this area, their home ground being Pindinnie [a permanent soak south of Mount Margaret] ... The various tribes such as roamed the goldfields areas ... each had there [sic] own section of country mapped out. ${ }^{\prime 76}$

Schenk and the other missionaries were aware of the strength of Aboriginal attachment to country, the strength of feeling for ngurra, the special, heartfelt area that provides each individual Aboriginal person with physical and spiritual sustenance and identity. ${ }^{77}$ When authorities were discussing whether Aboriginal children should be sent to Mount Margaret, where dormitories were being built,

refuted the migration theory, the Commissioner of Native Affairs referred to Schenk as 'a close observer of aborigines for the past 30 years'. See Western Australia, Commissioner of Native Affairs, Annual Report..., 1953.

74 Schenk 1935; Morgan 1985: 7, 10.

75 Western Australia, Aborigines Department, Report..., 1905: 6. Elkin, too, observed this, but confused the issue, saying, 'Man [i.e. desert Aborigines] is tied from his birth to his death to the rockholes' but the same people readily 'lose the desire to return' to their country (Elkin 1931-32: 49).

76 McDonald nd: 20.

77 Barnes et al: 3. This book contains numerous contemporary expressions of ngurra, the relationship between Wongatha people and their individual areas of country. 
or to the Moore River Native Settlement, the State Government facility near Perth, the missionaries declared firmly that the children should remain, 'in their own country'. ${ }^{78}$ Some years later, Schenk chided pastoralists who were lobbying to shift the mission: 'we say it is a sin to try to hunt [the district's Aborigines] out 130 miles past Laverton ... Anyone who tries to send natives out of their own district, either has no knowledge or no heart. ${ }^{.79}$

Further indication of the relationship to this specific region is signalled by Wongatha people asserting the right to control access. Early settlers and businessmen brought Aboriginal people from distant places to the northern Goldfields to serve as police trackers, drovers and animal herders. These 'stranger' Aborigines were often at considerable risk. In many Aboriginal societies, and certainly in the Western Desert, trespass was regarded as a serious breach of protocol that could be dangerous for the intruder. ${ }^{80}$ This was true in the Goldfields in the early contact period, where Aborigines Department Inspector Bailey observed, 'the tribal customs of Aboriginals forbid their entering the confines of other tribes, any departure from such customs usually result in combat, often death'. ${ }^{81}$

Basil, a Nyungar youth from the Northam area, taken to Murrin Murrin to mind a butcher's stock, was killed by local Aborigines in 1898, in large part because he was unknown. ${ }^{82}$ The same year, Wilbah alias Tiger, brought to Menzies from the north-west of the state also to undertake shepherding work was caught off guard and killed with a spear thrust into his back. There was general consensus that the accused in the latter case, five men from a group that occupied the country south of Laverton, had killed Wilbah because he was from out-of-country. ${ }^{83} \mathrm{~A}$ few years later, an attempt was made on the life of Banjo, an Aboriginal man from the Pilbara district serving as the police tracker at Malcolm. ${ }^{84}$ In this case, too, his stranger status was cause of the attack. ${ }^{85}$ It is unlikely these punishments for transgressing country would have been committed by people who were themselves newcomers and therefore trespassers.

Wongatha country was defended against larger incursions too. News that a party of kangaroo hunters, mostly Mirning people from the coastal country of the Great Australian Bight, was headed through the Kookynie district en route to the East Murchison at the end of the 1905 winter caused 'great consternation'

78 Morgan 1985: 107.

79 'Statement by Mr. R.S. Schenk', 1934, Con 987, item S, SROWA.

80 For example Tindale 1974: 24, 1976: 17; Myers 1986: 101; Skyring and Yu 2008: 63.

81 Bailey, CA, Report dated 15 October 1896, Con 495, item 45, SROWA. Though it had been mollified by the time the Wongatha native title claimants gave evidence in the early twenty-first century the need for people to get permission to enter the country of others remained strongly felt (see Federal Court of Australia 2007: paras 1408-1415).

82 Malcolm Chronicle and Leonora Advertiser, 5 December 1898.

83 Duncan, Report dated 16 October 1898, Con 430, file 4007/1898, SROWA; The Menzies Miner, 22 October 1898: 7.

84 Malcolm Chronicle and Leonora Advertiser, 23 May 1902.

85 Malcolm Chronicle and Leonora Advertiser, 23 May 1902. 
amongst the Wongatha because they were a large number of strangers. ${ }^{86}$ The warfare between the Laverton and Darlot Aborigines that cost a minimum 35 lives in six bloody years of the early twentieth century was variously attributed to action taken to punish wrong-way marriages or payback, ${ }^{87}$ but the constant descriptions were of two territory-based groups at the centre of the conflict. In 1937, Laverton constable Gravestock stated that Darlot Aborigines did not come closer to Laverton than the King of Creation mine, 50 kilometres north of Laverton and that when they did venture within Laverton country fighting usually resulted. ${ }^{88}$

Attachment to an area comes with a corollary, the oft-expressed antipathy to being on country that belongs to others. Expressions of this form a significant rebuttal of the migration assertion. Following his appearance before the Royal Commission, Schenk went public with his frustration at the continued lobbying to move the mission, and its Aboriginal residents, eastward. He declared that the Wongatha regarded any place 100 miles beyond Laverton 'as strange country', that many of the Mount Margaret people had never been that far eastward and that 'no humane treatment would ever induce them to go out there or to stay there' ${ }^{89}$ Decades later, Schenk's daughter related what she had learned growing up with the Mount Margaret Aborigines in the 1930s and 1940s:

Some, mind you, told me that they had come from Minnie Creek [to the east] but mostly people don't want to go out - You see, to go out to Warburton Ranges they are another complete different people. That's how they see them, you see; they are not the same people. In fact, to [her father's] amazement he found that Leonora people and Laverton people who frequented Cox's Find and Mulga Queen were two different people. So that they stayed in the [Laverton] district..$^{90}$

Resistance to being forcibly moved eastward continued in 1940 when the government planned to shift Mount Margaret people to the newly opened institution at Cosmo Newbery. Schenk wrote, 'Any risk of being sent to Cosmo will have a salutary influence because as it is a strange country to them they have a mortal fear of being sent there. ${ }^{91}$ Several dozen were nonetheless moved from Cox's Find, Mount Margaret and Laverton: within a short period, Superintendent A. J. Donegan remarked that his new charges were being made to overcome the 'taboo' they had expressed for the country they were now occupying. ${ }^{92}$

$* * *$

86 Kookynie Press, 12 August 1905: 4. Once it was ascertained the visit was not hostile, cordial relations were established.

87 Brodribb, H, Report dated 26 September 1910, Con 652, file 950/1910, SROWA.

88 Gravestock, J, Report dated 19 August 1937, Con 993, file 144/1937, SROWA.

89 Schenk 1935.

90 Morgan 1986.

91 Schenk, RS, Letter dated 20 October 1941, Con 993, file 421/1938, SROWA.

92 Donegan, AJ, Report dated 26 June 1940, Con 993, file 320/1940, SROWA. Underlining in original. 
Migration is understood to mean a process where newly developed stimuli cause usually voluntary and permanent movement to markedly different geographic, social and cultural places. Movement that is regular, temporary and/or within a common cultural zone is not migration. Some Aboriginal people did come inside the northern Goldfields frontier, but before that movement can be labelled the reasons why it occurred must be examined.

Long before European settlement, occupation of the Western Desert was a dynamic process that involved a two-fold strategy: 'drought evasion', where the individuals or families from a particular area stayed within their territory but moved towards and then were restricted to a small number of the most reliable water sources, ${ }^{93}$ or 'drought escape', which included regular temporary abandonment of the very driest areas in favour of various refuges - hilly or granite country that retained permanent water supplies. ${ }^{94}$ The amount of rainfall and surface water availability determined the patterns adopted, ${ }^{95}$ and the desert groups needed to maintain good relations with the people of the areas into which they moved.

This pattern was identified in the immediate pre-settlement period. The explorer Charles Hunt, south of Kalgoorlie in 1864, met a group of Aboriginal people who had come from the arid country to the east and were headed for the granite country to wait out the hot weather. ${ }^{96}$ Returning the following year and in 1866, in the same general location, he was told again of the regular tactic of travelling westward during the summer dry periods. ${ }^{97}$ In 1891, the Elder Scientific Exploring Expedition, under the leadership of David Lindsay, made its way northward through the scrub country on the western edges of the Great Victoria Desert preparing for a return crossing through central Australia. There had been no rain in this country for three years and, because of the severe drought, people had left their desert country where there was no water and headed west beyond Leonora. ${ }^{98}$

In the post-settlement period, Aboriginal decisions were still made first and foremost in response to climatic oscillations and only subsequently by the presence of Europeans. A large group of Aborigines arrived in the Laverton area in midsummer 1904 and moved back to the spinifex country when sufficient winter rains had fallen. ${ }^{99}$ This movement was repeated during the dry years of

93 Gould 1991.

94 Veth 1989, 2002; Gould 1991.

95 Veth 1987.

96 Hunt 1864, Journal of Exploration Eastward of York in 1864, facsimile edition, publication details unknown, Battye Library: 61.

97 Hunt Journal, 16 June and 7 July 1865, unpublished, Battye Library; Hunt 'Exploration Journal of an Expedition to the Eastern Interior of Western Australia, by Mr. C.C. Hunt', in Exploration Diaries, unpublished, Battye Library: 47.

98 Lindsay 1893: 56

99 Laverton Mercury, 29 January 1904; Brown, ED, Letter dated 9 September 1904, Con 255, file 375/1904, SROWA. 
1910 and 1911. ${ }^{100}$ The year 1914 was until 2001 the worst drought year in the south-western part of the continent since Europeans began keeping records. The police report from Laverton that year was unequivocal: 'The drought was responsible for the large number of indigents. ${ }^{\prime 101}$ The result was that government rationing at the various northern Goldfields centres increased rapidly, but then declined sharply in subsequent, wetter, years as people returned to the bush. ${ }^{102}$

Chief Protector Neville saw a regular impact on his budget, commenting that in the Leonora district, 'we must expect some addition to our indigent lists at the end of the long dry summer before the advent of the winter rains. It has been the same for years'. ${ }^{103}$ A decade later, Neville's minister gave an overview of Aboriginal movements across the northern Goldfields frontier:

during dry times the natives invariably come into the feeding depots in great numbers. As soon as the heavy rains fall, most of these natives will disperse, leaving the local tribes only on the ration lists. ${ }^{104}$

In 1917, Constable O'Loughlin noted a group of local Aborigines returning to Murrin Murrin from a 12-months absence in the bush, ${ }^{105}$ while at Leonora, after good rains fell in 1915, police advised that the Aboriginal people had gone into the bush seeking food. ${ }^{106}$ When rains fell in the early winter of 1932, the Kalgoorlie Miner reported the desert groups had moved back into the spinifex, 'taking advantage of the cool weather and in expectation of ample water supplies in the various rock holes on the eastern boundaries, where game should be plentiful' ${ }^{107}$

Secondary to the need for water was the availability of both game and vegetation supplies. Populations of Macropus rufus - the red kangaroos that are an important food source for Aboriginal people in the Western Desert region - fluctuate according to drought and have done so since before the arrival of Europeans. ${ }^{108}$ People followed these to areas where rain has recently fallen. ${ }^{109}$ Vegetation is of greater importance: it is generally reckoned that vegetable foods comprise between 50 and 80 per cent of the traditional diet of Western Desert Aborigines. ${ }^{110}$ Usually, when it rained in an area, people moved there to hunt the animals that came to feed on the fresh shoots of grass and to collect

100 Western Australia, Aborigines Department, Report..., 1910; Laverton Mercury, 23 December 1911.

101 Western Australia, Aborigines Department, Report..., 1914: 48.

102 In 1914, approximately 70 of the reported 400 Aborigines in the district (17.5 per cent) were receiving government rations (see Western Australia, Aborigines Department, Report..., 1914: 48). The following year, the equivalent figures were 15 of 425 , or 3.5 per cent (see Western Australia, Aborigines Department, Report..., 1915: 27) and in 1916 they were 20 of 400, or 5.0 per cent (see Western Australia, Aborigines Department, Report..., 1916: 51).

103 Neville, AO, Letter dated 27 February 1919, Con 1667, file 107/1927, SROWA.

104 Kitson, WH, Report dated 17 March 1930, Con 993, file 431/1928, SROWA.

105 O'Loughlin, Letter dated 18 July 1917, Con 993, file 19/1927, SROWA.

106 Haly, Arthur, Letter dated 22 December 1915, Con 1667, file 107/1927, SROWA.

107 Kalgoorlie Miner, 23 April 1932: 2.

108 Department of Conservation and Land Management 2002: 39, 41.

109 Gould 1991.

110 Meggitt 1957; Gould 1969. 
mulga, grass and murrin murrin seeds to grind into flour. ${ }^{111}$ Kookynie constable Dodd counted 200 Aboriginal people at Kookynie in 1909 and noted they 'travel around \& as the game becomes scarce \& they cannot get sufficient food they move on to another part of their Country or District'. ${ }^{112}$

Dodd's comment hints at the changing economic systems European settlement brought. These - pastoralism in particular - placed much greater pressure on the country's natural flora and fauna resources and made gaining sustenance from the land difficult. Kangaroos and dingoes were killed while the animals brought in to stock the northern Goldfields pastoral stations destroyed the native vegetation. Concerned newspaper editors noted on several occasions the Aboriginal people's vulnerability to the appropriation of land and the shooting and poisoning of game. ${ }^{113}$ Constable Perks at Morgans noted in the mid 1920s the problems caused when a poor season exacerbated the lack of game and a shortage of murrin murrin seeds. ${ }^{114}$

Any doubts about the deleterious effect on diet are dispelled by a comparison between reports on the health of Western Desert people before and after the mass arrival of Europeans. Various descriptions given in 1892 and 1893 declared of the people living outside the range of European settlement, 'most of them [were] of fine physique', 115 'a fine, tall, stalwart race of men, with handsome women', 116 'getting fat' on the plentiful game. ${ }^{117}$ '[A]s to their physique they were certainly in advance of the semi-civilized aborigines seen in the neighbourhood of large towns.' ${ }^{\prime 18}$ As late as 1931, people beyond the frontier were in better health. Surveyor H. L. Paine found the people he met who lived in the Warburton Range area, far beyond the frontier, were 'healthy and unspoiled ... particularly well-built people' ${ }^{119}$ At the time of the first European settlement, Western Desert Aborigines were seen as, 'a laughing, careless race, full of humour, mirth and song', people who displayed an 'extreme buoyancy of spirits', ${ }^{120}$ a 'happy and careless race' ${ }^{121}$

This changed dramatically as vital resources were lost. When the Elder expedition arrived at Fraser Range station, a pastoral station in the southern Goldfields in 1891, they found the Ngadju there were faring poorly. ${ }^{122}$ Expedition naturalist Helms blamed this squarely on the insufficient food available on and

111 McDonald, nd: 15, 20-21.

112 Dodd, J, Letter dated 13 September 1909, Con 652, file 579/1909, SROWA.

113 For example, Kalgoorlie Miner, 19 April 1900: 7, 28 February 1905: 2; Laverton Mercury, 19 April 1907.

114 Perks, SE, Report dated 19 December 1924, Report dated 28 September 1925, Con 993, file 19/1927, SROWA.

115 Lindsay 1893: 3.

116 Lindsay 1893: 6.

117 West Australian, 6 September 1895: 6.

118 Gillett 1892: 80.

119 Paine, 'Report and Journal of Surveyor H.L. Paine, Leader of the Warburton Range Expedition 26th May 1931 - 17th Oct. 1931', unpublished, Battye Library: 4, 12.

120 Raeside 1996: 95.

121 Bailey, CA, Report dated 14 February 1897, Con 495, item 47, SROWA.

122 Lindsay 1893: 3. 
near the station. ${ }^{123}$ Victor Streich, another member of the expedition, returned to survey in the now settled Goldfields in 1904 and noted that since his first visit native game had disappeared and spinifex, which did not provide an edible food resource, had spread. ${ }^{124}$ Prospector Albert Gaston described the effects as European settlement wended its way north in the mid-1890s:

The few blacks around Coolgardie were the most miserable, half-starved creatures I have ever seen. The further one goes north the better the blacks seem to be physically. Around Mt. Margaret were some very strong and well-made men. In that district game is a little more plentiful. ${ }^{125}$

Within a decade, the wretched conditions of near starvation around Kalgoorlie were replicated further north. ${ }^{126}$ Newspapers repeatedly asked for assistance for the underfed northern Goldfields Aborigines, ${ }^{127}$ with the Laverton Mercury in 1910 lambasting the government and the Aborigines' Protection Board for its inaction, going as far as to say that the desired outcome of driving the Wongatha out of Laverton could not be achieved because they would die in the desert. ${ }^{128}$ Whether because of inconsistent rain or settlement, people had no choice; they came westward to find food and water.

There were other reasons for moving westward which remained within the framework of pre-contact Aboriginal identity. People came to find partners: 'marrying far away' was considered a way to ensure that 'right way' marriages occurred. ${ }^{129}$ That is, in the sparsely populated arid country east of Laverton, finding a suitable partner from the right skin group usually meant travelling great distances. Another compelling reason was the fighting and payback killings that occurred periodically in the desert. ${ }^{130}$ After Mount Margaret was established in 1922 people brought their children in, not because they were responding to the lure of the place but in order to avoid having the children removed much further afield to Moore River. ${ }^{131}$

Far from being a lure, being near the towns was not necessarily the most desirable option. From A Drop in a Bucket, written by Margaret Morgan, Rod's and Mysie's daughter, based on her parents' diaries and letters, Rod Schenk's discomfort at the scene he witnessed at Laverton in 1921 is clear:

Constable Hunter, mounted on horseback, charging down on groups of Aboriginal outcasts with stockwhip flaying out in all directions. The sound of the crack of the whip, the whirls of dust, the screams of

\footnotetext{
123 Helms 1896: 241.

124 Kookynie Press, 28 September 1904: 4.

125 Gaston 2007: 180.

126 Western Argus, 20 June 1895: 5; Coolgardie Miner, 14 December 1895, 2 and 25 July 1896.

127 Laverton Mercury, 19 April 1907 and 15 January 1910; Mount Leonora Miner, 4 January 1908.

128 Laverton Mercury, 15 January and 17 September 1910.

129 Federal Court of Australia 2007: especially section 4.7.

130 Cooper, L in Federal Court of Australia 2007: para 981.

131 Forrest, I in Federal Court of Australia 2007: para 254.
} 
women and children, angry shouts of men, terror-stricken faces - that picture was printed indelibly on [Rod Schenk's] memory. The little yulira (friendless) mob ran for their lives before the onslaught.

Rod found out it was a daily occurrence. ${ }^{132}$

Unsurprisingly, then, many preferred to stay away from the towns. Aborigines Department official Brodribb, sent to Laverton in 1910, was told about the numerous Spinifex Natives, many of whom never come in, and are practically wild' ${ }^{133}$ Former Laverton resident John Thompson recalled that in the early twentieth century Aboriginal people mostly stayed in the bush, ${ }^{134}$ while Gravestock reported in 1938 that 'most of the natives would sooner be in the bush provided they received some Rations' ${ }^{135}$ At this time, visits by groups from the desert were still uncommon enough to excite comment, ${ }^{136}$ as when Schenk and the Commissioner of Native Affairs exchanged notes, agreeing that such visits only occurred when the seasons were particular poor in the desert - on average every four or five years - and even this did not guarantee people would come in. ${ }^{137}$

Moving near the towns was more likely to result from being pushed out of the arid zones rather than pulled in by the temptations of settlement. The distinction is important: moving voluntarily might be expected to cause a psychological break with the original area of country as a new area was deemed better. If, however, people were forced to move because the alternative was starvation then such a shift in how people conceptualised the country they were leaving and the country they were going to would not occur. In this case, Wongatha people moving westward to spending more time in association with Europeans did not signal dis-attachment from country or modification of traditional customs.

Many people remained in the bush east of Laverton. Implicit in the reports of hunting and gathering is that the Aboriginal people in question had knowledge of the resources there. Such knowledge - the basis of attachment to country - is not readily gained; these were people who belonged to this country. Schenk came to know them well. He had alerted the Aborigines Department to their origins in 1937, correcting Laverton Constable Gravestock's advice that Aborigines from the Warburton Range were in the district. Schenk wrote how connections to country were expressed:

132 Morgan 1985: 6-7.

133 Brodribb, H, Report dated 26 September 1910, Con 652, file 950/1910, SROWA.

134 Thompson 1976.

135 Gravestock, J, Report dated 29 November 1938, Con 993, file 144/1937, SROWA.

136 Gravestock, Report dated 29 November 1938, Con 993, file 144/1937, SROWA.

137 Neville, Report dated 10 August 1937, Con 993, file 144/1937, SROWA; Schenk, RS, Letter dated 19 April 1937, Con 993, file 144/1937, SROWA. 
many natives that Constable Gravestock calls Warburton natives come from places less than halfway out to Warburtons [sic], and Constable Gravestock would find this is correct by asking them which is their particular water hole. ${ }^{138}$

Schenk worried that if he had to move the mission the Wongatha would stay put and he would be working with an entirely new group. ${ }^{139}$ Soon, though, his pragmatism reasserted; instead of moving, Schenk offered to open a branch of the mission at Cosmo Newbery, 80 kilometres north-east of Laverton, in the spinifex, ${ }^{140}$ with the intention of proselytising among the easterly group. ${ }^{141}$ Gravestock became supportive, suggesting that a mission outstation would provide a means of stopping people crossing the pastoral stations in the region and visiting Laverton and nearby Beria. ${ }^{142} \mathrm{He}$ favoured Burtville as the location but suggested also Claypan Well, some 60 kilometres east of Laverton, already a meeting and camping place for the eastern group. Schenk's preparedness to expend the time, effort and money required to establish a new mission affirms the ongoing Aboriginal presence in the country east of Laverton - a group of people who would not permanently move to Mount Margaret or near any other town in the northern Goldfields.

A final, crucial condition needs to be met before the movement of subsistence hunter-gatherers can be labelled migration: the people in question must have crossed cultural boundaries. Movement within traditional cultural and economic orbits constitutes no more than normal seasonal ranging. Evidence provided over a long period suggests that the Aboriginal people crossing the northern Goldfields frontier were not also crossing into strange country.

David McDonald recorded that the country of two of the northern Goldfields groups with which he was most familiar extended eastward from Pindinni Soak and Edjudina, respectively. ${ }^{143}$ This tallied with the impressions gained by two Aborigines Department employees; Travelling Inspector L. C. M. Beurteaux, who said the Aboriginal group he encountered in the northern Goldfields in 1909 travelled in a circuit between the towns of Morgans and Laverton, north to Mulga Queen and eastward into the spinifex country, ${ }^{144}$ and H. Brodribb, who noted that the Aborigines of the Laverton district were closely aligned with those living in the spinifex country to the east. ${ }^{145}$

138 Schenk, RS, Letter dated 23 August 1937, Con 993, file 144/1937, SROWA.

139 Schenk 1935.

140 Schenk 1935.

141 Schenk, RS, Letter dated 30 March 1937, Letter dated 19 April 1937, Con 993, file 144/1937, SROWA.

142 Gravestock, J, Report dated 19 August 1937, Con 993, file 144/1937, SROWA.

143 McDonald, nd.

144 Beurteaux, ECD, Report, 28 May 1906, Con 255, file 423/1906, SROWA.

145 Brodribb, H, Report dated 26 September 1910, Con 652, file 950/1910, SROWA. 
During the winter of 1931, the surveyors Paine and Barclay traversed the country between Laverton and the Warburton Range. The two men were briefed and professionally inclined to provide detailed descriptions of the spinifex country and they spent weeks in the company of a dozen or more Laverton-area Aborigines. Their reports are thus replete with ethnographic comment that now provides valuable insight into territorial limits, reciprocal rights within those territories and the exchange of initiates. Patent tensions that existed eliminate the possibility that the Laverton people had originated from the Warburton area over the three decades leading up to Paine and Barclay's survey:

[The Aborigines] accompanied us until we neared the boundary between the Laverton and Warburton tribes. Then the Laverton people broke away in different directions and in small groups, while the Warburton people stayed with us. By the way the Laverton people spoke to us it was evident that they were somewhat afraid of the Warburton's [sic] - yet they appeared to permit a few Warburtons [sic] at a time to come through their own tribal territory and to remain in Laverton for a period. We were not able to find out what agreements existed or what formalities were observed by the visitors ... the Laverton tribe would not intrude into Warburton tribal country even though they were prepared to receive a few Warburton boys and let them come into Laverton. ${ }^{146}$

Later, north of Baker Lake:

The Natives who have followed us from Laverton have been busy since arriving at this place (Winduldarra) in making womeras (Wally-ma) and doing up their weapons generally. Apparently they expect to meet newer people shortly. Frankie [the guide from Laverton] told me that 'sulky fella' is about two sleeps away, and yet he says the Warburton Natives are 'good fella'. Maybe there is more than one tribal boundary 'close up'. ${ }^{147}$

Reaching Minnie Hill in the Warburton Range, the Laverton people were,

becoming anxious as to the further extent of our easting. Must be near the end of their permits. One ... admitted that "Black fella out there might be little bit sulky fella", and was very relieved when I told him that Bhilbring [nearby Lightening (sic) Rock, east of Warburton] is as far as we go. ${ }^{148}$

Others support this information. The Laverton correspondent to the Kalgoorlie Miner wrote in 1930 that the local Aborigines, 'cover country from Laverton 200 to 250 miles east, over their particular area or boundary, never daring to

146 Barclay nd, The Aborigines of the Area in Western Australia between the town of Laverton..., Battye Library: 4, 11.

147 Paine, 'Report and Journal of Surveyor H.L. Paine, ... 26th May 1931 - 17th Oct. 1931', unpublished, Battye Library: 9-10.

148 Paine, 'Report and Journal of Surveyor H.L. Paine, ... 26th May 1931 - 17th Oct. 1931', unpublished, Battye Library: 21. 
encroach on their fellowmans' boundary, north or south', ${ }^{149}$ while during 1939, local pastoralist W. A. Ross wrote of Aboriginal people coming in to Laverton, 'their home-land is from Laverton Eastward'. ${ }^{150}$ The group described would not travel as far west as the Mount Margaret Mission area, which seemed to be strange country to them. As a child in Laverton, John Thompson recalled an incident in the first decade of the twentieth century when strangers came in from a lot further east than usual and were unknown to the local Aborigines. ${ }^{151}$

Consistently, descriptions show that most of the people at Laverton belonged to a group whose cultural and subsistence orbit extended eastward somewhere between 200 and 400 kilometres. The fuzziness of the described boundary is expected; typical of such mobile hunter-gatherer groups in sparsely populated country and a result of uncertain observations by Europeans. People coming in to Laverton from this region were remaining within their traditional country - additional proof that 'migration' is not a valid description. (It was, however, a long-lasting impression. In the Wongatha decision, Lindgren, J. found that the majority of the claimants were descended from people who migrated into the claim area. ${ }^{152}$ This was not borne out in the Wongatha witnesses' evidence. Fewer than 30 per cent of claimant witnesses stated they were born outside the claim area, 31.4 per cent of parents of witnesses were stated to have come from outside the claim area and just over ten per cent of grandparents had similar origins. For many parents and the great majority of grandparents either no place of origin was given or they were not Aboriginal.) $)^{153}$

In attempting to understand Aboriginal life, commentators in Australia have constructed metaphors that made Aboriginality more comprehensible where it was otherwise unfamiliar and abstract. Aboriginal cultural groupings have been described as 'nations', 'tribes' and 'clans', terms introduced, used, debated and often rejected through the course of Australian anthropology. ${ }^{154}$ The heartfelt places in Aboriginal lives noted above are often referred to as 'Country' but this too is a metaphor that describes a relationship between individual and place in non-Aboriginal terms, while ngurra remains a difficult concept to describe. ${ }^{155}$

149 Kalgoorlie Miner, 27 September 1930: 2.

150 Ross 1939.

151 Thompson 1976.

152 Federal Court of Australia 2007: para 1167.

153 See Federal Court of Australia 2007: Annexure F.

154 For example Berndt 1959; Berndt and Berndt 1988; White 1985: 36; Hiatt 1996: 20-21.

155 Even Myers (1986: 48), author of the authoritative Western Desert study, Pintupi Country, Pintupi Self, struggles here, translating the concept of ngurra as 'camp,' 'country' or 'place,' a starkly broad range of possibilities. Equally, the framers of the Wongatha native title claim could not provide a culturally accurate legal description, conceptualising ngurra as, 'a person's birth place, camp or home or area of ancestral connection, having primary importance and "run", being a broader area signifying a range of occupation' (Federal Court of Australia 2007: para 138). None of this captures the term's emotional content (e.g. Federal Court of Australia 2007: Annexure F). 
The entire Aboriginal ontology has been named 'Dreamtime', evoking a certain understanding for non-Aboriginal people but a problematic term ${ }^{156}$ that falls well short of the explanation it purports to be. ${ }^{157}$

Thinking of Aboriginal seasonal traditional movement as migration served such a purpose, putting Aboriginal life into a historicised and westernised context but one which erases Aboriginal agency. In the Australian discourse of the previous century migration most often refers to a process whereby the less fortunate sometimes inferior - improve their lives by physical and cultural relocation to mainstream Australian society. (Remember: this was a European population which had migrated to the Goldfields seeking economic improvement, shaping their thinking in the process.) So too the people of the desert were drawn haplessly towards European settlement.

Construction of the migration metaphor happened as relations between settlers and Aboriginal people in the northern Goldfields changed and Aboriginal identity was reimagined. During the initial prospecting period of 1894-96, many encounters between Aborigines and Europeans occur in fraught, ad hoc circumstances at places of heightened significance (most often, scarce water sources). Descriptions of Aboriginal people, often employing the language of military conflict, were made in this adversarial context.

Half a decade on, the local mining economy had changed. Company-owned ventures superseded the scattered masses of prospectors who operated in the region in the first instance. This changed the nature of daily contact between Aborigines and Europeans. With well-established, centralised mining and safe transport routes the gold extraction industry had no real interest in controlling large areas of landscapes and the colonising narrative was reordered. The war was over; Aboriginal people had lost and it was now permissible to publicly recognise their moral (though not legal) rights to the land. At the turn of the century, each of the northern Goldfields newspapers referred to, variously, the 'the original owners of this soil', 'the coloured natives of [the region's] soil', 'the original owners of the big Mt. Margaret territory', and 'the rightful owners of the soil'. ${ }^{158}$

Elkin's visit came at the cusp of a second change in Aboriginal-European relations in the northern Goldfields. Mining's importance had diminished slightly but a more significant change in the northern Goldfields economy had occurred with the establishment and rapid growth over the preceding quartercentury of a pastoral industry. Pastoralism used the land far more extensively and thus discouraged acknowledgment of Aboriginal ownership. The historical justification that Aboriginal people forwent private property rights because

156 Berndt and Berndt 1988: 229.

157 See especially Wolfe 1991, 1997; also Stanner 1970; Myers 1986: 47.

158 Mount Leonora Miner, 8 March 1902; Malcolm Chronicle and Leonora Advertiser, 24 June 1904; Laverton Mercury, 23 November 1901 and 19 April 1907. 
they did not invest their labour in the land re-emerged in new guise: Aboriginal connection to the land would not need to be acknowledged if it could be said that Aboriginal people had displaced themselves.

In this newer, pastoral context, Aboriginal people in the northern Goldfields were denied their local place, described instead as a nuisance, floating population ${ }^{159}$ who formed an 'objectionable presence', 160 illegitimately dependent on European largesse because they were off their own country. Before the 1934 Moseley Royal Commission and then in print a few years later, Rod Schenk voiced his concern that the history of Aboriginal people in the region was being reforged:

Wherever one meets a number of natives the usual complaint is that they came from further out, and should be driven back... Likewise they said the natives at Laverton all came from the ranges of the interior and should be sent back... Why occupy the country and then resent the presence of the natives in the district? Those who reiterate that the native race has got to go thereby provide evidence conclusive against their own policy of securing all the good land. ${ }^{161}$

The pastoralists who said this were not drawing on Elkin but in their equal failure to understand what Aboriginal people were doing both resorted to a constructed explanation. The migration experience was already deeply embedded in the worldview of non-Aboriginal Australians. In a different context it was also what the pastoralists and Elkin expected of Aboriginal people; that they would be drawn almost helplessly from their lands by the promise of betterment.

Both Elkin and the pastoralists are shown to be wrong by other sources who were their contemporaries. Often, primacy is attached to historical material generated by earlier professional researchers over that produced by non-professionals making ad hoc observations. In this part of the Western Desert, this has led to compounding error. Aboriginal people in the northern Goldfields made decisions based on need, moving back and forth to places of supply and/or remaining within their traditional cultural region and range of subsistence foraging. Here, migration was not the process in which Aboriginal people were involved, but a misnomer which has had deprecating consequences in the long run.

\section{Acknowledgments}

I would like to thank those Wongatha and Aboriginal people from other groups who have been patient in telling me their histories. I have followed up ideas generated while undertaking native title research at my former place of employment, the Goldfields Land and Sea Council. Colleagues and Board members there, where research is but one part of an overextended and

\footnotetext{
159 See, for example, Western Australia, Aborigines Department, Report..., 1900: 6, and 1902: 8; Malcolm Chronicle and Leonora Advertiser, 3 June 1904; Laverton Mercury, 17 March 1921.

160 Malcolm Chronicle and Leonora Advertiser, 20 January 1905.

161 'Statement by Mr. R.S. Schenk', 1934, Con 987, item S, SROWA, Schenk 1937: 30.
} 
underfunded organisation, were consistent in their support. Much of this research took place at the Battye Library and the State Records Office of Western Australia where staff have also been particularly helpful. Thanks also to the Department of Indigenous Affairs (as it was) for assistance in getting access to various files held under their control.

\section{References}

\section{Archival sources}

Barclay, Hugh C 1931, The Aborigines of the Area in Western Australia between the town of Laverton, the Warburton Ranges to the northeast of that town and Lightening Rock to the East of the Ranges, the latter being about 60 miles west of the southwestern corner of the Northern Territy, as visited by a survey team from the Dept of Lands and Surveys of WA in 1931, publishing details unknown, Battye Library, Western Australia.

Elkin, AP 1930, 'notebook 8', A.P. Elkin Collection, Fisher Library, University Archives, University of Sydney, accession 664, item 1/2/8.

Hunt, CC 1864, Journals of Exploration Eastward of York in 1864, facsimile edition, publication details unknown, Battye Library, Western Australia.

- 1865, Journal by CC Hunt, unpublished, Battye Library, Western Australia.

- 1866, 'Exploration Journal of an Expedition to the Eastern Interior of Western Australia, by Mr. C.C. Hunt', in Exploration Diaries, unpublished, Battye Library, Western Australia.

McDonald, David nd, Biography (D.S. McDonald), unpublished typescript, Battye Library, MN1124 Accession 3406A, item1.

Paine, HL 1931, 'Report and Journal of Surveyor H.L. Paine, Leader of the

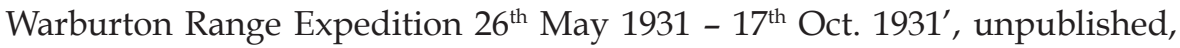
Battye Library, Perth, Western Australia.

Thompson, John 1976, Interview with Jean Teasdale, Battye Library, Western Australia.

State Records Office of Western Australia (SROWA)

Consignment 255, Files - Chief Protector of Aborigines

file 29/1904, Native Affairs Kookynie

file 40/1903, Re Natives Menzies District 
ABORIGINAL HISTORY 2014 VOL 38

file $145 / 1899$

file $172 / 1900$

file 375/1904, Reported large number destitute natives at Duketon. Mt. Margaret G.F.

file 423/1906, Travelling Inspector Report. Re. Condition Ab. Natives - E. Gold Fields.

file 712/1908

Consignment 430, Police Department: General Files, 1876-1971

file 849/1897, Journal of P.C. Glass

file 1557/1897, Journal of P.C. Glass

file 2006/1897, Journal of P.C. Glass

file 2199/1895, Reported outrage committed at Mt Margaret - Two white men \& some natives shot by four men.

file 4007/1898, Menzies Ab native Tiger speared by hostile blacks.

file 4119/1896, Journal of P.C. Glass.

file 5209/1900, Aborigines \& their dogs about Mt Morgans, complaints re

Consignment 431, Mount Margaret Police Station

item 1, Mount Margaret police occurrence book.

Consignment 495, Aborigines Protection Board, - Correspondence \& Report, 1892-1894.

item 45

item 47

Consignment 652, Files - Department of Aborigines and Fisheries

file 160/1909

file 479A/1911, Correspondence Blankets 1911 - 1912 - 1913 Clothing

file 579/1909, Rationing Natives - Kookynie - Provision for.

file 950/1910, Raid by Darlot-Leonora natives on natives encamped at Laverton.

Consignment 987, Moseley Royal Commission 
item S, Statement by Mr. R.S. Schenk, Moseley Royal Commission.

Consignment 993, Files - Aborigines Department

file 19/1927, Native Matters - MT. MORGANS.

file 144/1937, LAVERTON. Proposed Native Station in the Vicinity. (Cosmo Newbery Station).

file 195/1936, MENZIES - Native Matters.

file 320/1940, Cosmo Newbery Native Settlement. PROGRESS REPORTS OFFICER IN CHARGE.

file 369/1926

file 421/1938, Mt. Margaret Mission - Register of Inmates RETURNS.

file 431/1928, MT. MORGANS GOSPEL MISSION. (1) Suggested removal of further inland. POINT SALVATION- (2) Allocation of 1 Million acres reserve. Reserve 20396 - 500,000 acres.

file 487/1937, Mt Margaret Mission - NATIVE MATTERS.

file 691/1938, Back to the Goldfields Celebrations - Permission for natives to take part in.

Consignment 1667, Files - Aborigines Department

file 107/1927, LEONORA - NATIVE MATTERS -

Consignment 3354, Laverton Police Station

item 1, Laverton police letter book

\section{Official printed sources}

Western Australia, Aborigines Department, Report for Financial Year Ending 30th June..., 1900, 1901, 1902, 1905, 1908, 1910, 1914, 1915, 1916, Government Printer, Perth, Western Australia.

Western Australia, Chief Protector of Aborigines, Annual Report of Chief Protector of Aborigines for the Year Ended 30th June..., 1930, 1931, Government Printer, Perth, Western Australia.

Western Australia, Commissioner of Native Affairs, Annual Report of the Commissioner of Native Affairs for the Year Ended 30th June ..., 1953, Government Printer, Perth, Western Australia. 
ABORIGINAL HISTORY 2014 VOL 38

\section{Newspapers}

Coolgardie Miner

Kookynie Press

Laverton Mercury

Malcolm Chronicle and Leonora Advertiser

Menzies Miner

Mount Leonora Miner

West Australian

Western Argus

\section{Secondary sources}

Barnes, Cyril et al 2007, Ngayuku Kapi: Stories from the North-East Goldfields, Goldfields Land and Sea Council, Kalgoorlie.

Berndt, Ronald M 1959, 'The concept of 'The Tribe' in the Western Desert of Australia', Oceania 30(2): 81-107.

Berndt, Ronald M and Catherine H Berndt 1988, The World of the First Australians: Aboriginal Traditional Life: Past and Present, Aboriginal Studies Press, Canberra.

Carnegie, David W 1982, Spinifex and Sand, Hesperian Press, Victoria Park, Western Australia.

Dauth, Tim 2011, 'Group names and native title in south-east Australia', in Unsettling Anthropology: The Demands of Native Title on Worn Concepts and Changing Lives, Toni Bauman and Gaynor Macdonald (eds), AIATSIS, Canberra: 21-40.

Department of Conservation and Land Management 2002, Red Kangaroo (Macropus rufus) Management Plan for Western Australia, 2003-2007, Department of Conservation and Land Management, Western Australia.

Elkin, AP 1930,'notebook 8', accession 664, item 1/2/138, University of Sydney.

Elkin, AP 1931-32, 'The social organisation of South Australian tribes', Oceania 2(1): 44-73.

- 1943, The Australian Aborigines: How to Understand Them, 2nd edition, Angus and Robertson, Sydney/London. 
- 1980, 'Aboriginal-European relations in Western Australia: an historical and personal record', in Aborigines of the West: Their Past and Their Present, Ronald M Berndt and Catherine H Berndt (eds), University of Western Australia Press, Perth: 285-323.

Federal Court of Australia 2004, The Alyawarr, Kaytetye, Warumungu, Wakay Native Title Claim Group v Northern Territory of Australia [2004] FCA 472, (Mansfield J), <http://www.judgments.fedcourt.gov.au/judgments/Judgments/fca/ single/2004/2004fca0472> (accessed 30 January 2014).

-2007, Harrington-Smith on behalf of the Wongatha People v Western Australia (No 9) [2007], FCA 31, (Lindgren J), <http://www.austlii.edu.au/cgi-bin/ sinodisp/au/cases/cth/FCA/2007/31.html?stem=0\&synonyms=0\&query= Harrington-Smith> (accessed 9 January 2014).

Forrest, John 1969, Explorations in Australia: I.-Explorations in Search of Dr. Leichardt and Party. II. - From Perth to Adelaide, Around the Great Australian Bight. III. - From Champion Bay to the Telegraph and to Adelaide. With an Appendix on the Condition of Western Australia, facsimile edition, Gilbert and Rivington, London.

Gaston, Albert 2007, Coolgardie Gold: Personal Record, Hesperian, Carlisle, Western Australia.

Gillett, CS 1892, 'Exploration in Western Australia between Northam and Eucla, in 1887, by Mr. Gillett', Proceedings of the Royal Geographic Society of Australasia, Government Printer, Sydney.

Gould, Richard A 1969, 'Subsistence behaviour among the Western Desert Aborigines of Australia', Oceania 39(4): 253-274.

- 1991, 'Arid-land foraging as seen from Australia: adaptive models and behavioural realities', Oceania 62(1): 12-33.

Haebich, Anna 1992, For Their Own Good: Aborigines and Government in the South West of Western Australia 1900 - 1940, University of Western Australia Press, Nedlands, Western Australia.

Helms, Richard 1896, in Transactions of the Royal Society of South Australia 16(3), Ralph Tate (ed), WC Rigby, Adelaide, South Australia.

Hiatt, LR 1996, Arguments about Aborigines: Australia and the Evolution of Social Anthropology, Cambridge University Press, Cambridge.

Lindsay, David 1893, Journal of the Elder Exploration Expedition, 1891, South Australian Government, South Australia. 


\section{ABORIGINAL HISTORY 2014 VOL 38}

McGregor, Russell nd, 'Intelligent parasitism: A.P. Elkin and the rhetoric of assimilation', API Network 3, <http:/ / www.api-network.com/main/pdf/ scholars/jas51_mcgregor.pdf> (accessed 28 June 2007).

Meggitt, MJ 1957, 'Notes on the vegetable foods of the Walbiri of Central Australia', Oceania 28(2): 143-145.

Merlan, Francesca 2006, 'European settlement and the making and unmaking of Aboriginal identities', The Australian Journal of Anthropology 17(2): 179-195.

Morgan, Margaret 1985, A Drop in a Bucket: The Mount Margaret Story, United Aborigines Mission, Box Hill, Victoria.

Morton, John 1998, 'Essentially black, essentially Australian, essentially opposed: Australian anthropology and its uses of Aboriginal identity', in Pacific Answers to Western Hegemony: Cultural Practices of Identity Construction, Jürg Wassmann (ed), Berg Publishers, Oxford: 355-385.

Myers, Fred R 1986, Pintupi Country, Pintupi Self: Sentiment, Place, and Politics among Western Desert Aborigines, Australian Institute of Aboriginal Studies, Canberra.

National Native Title Tribunal 2012, National report: native title, <http:// www.nntt.gov.au/News-and-Communications/Publications/Documents/ Corporate\% 20publications/NNTT-national-report-card-February-2012.pdf> (accessed 30 January 2014).

Pitty, Roderic 1999, 'A poverty of evidence: abusing law and history in Yorta Yorta v Victoria (1998)', Australian Journal of Legal History 5: 41-61.

Raeside, Jules 1996, Golden Days: Being Memoirs and Reminiscences of the Goldfields of Western Australia, Hesperian Press, Carlisle, Western Australia.

Reilly, Alexander 2000, 'The ghost of Truganini: the use of historical evidence as proof of native title', Federal Law Review 28: 453-475.

Ross, WA 1939, Letter printed in the West Australian, 3 June 1939.

Schenk, RS 1935, Letter printed in the West Australian, 11 April 1935.

- 1937d, The Educability of the Native, Service Printing Co for UAM, Perth.

Skyring, Fiona and Sarah Yu 2008, "Strange strangers": first contact between Europeans and Karajarri people on the Kimberley coast of Western Australia', in Strangers on the Shore: Early coastal contacts in Australia, Peter Veth, Peter Sutton and Margot Neale (eds), National Museum of Australia, Canberra: 60-75. 
Stanner, WEH 1970, 'The Dreaming', Cultures of the Pacific, in T Harding and B Wallace (eds), Free Press, New York: 304-315.

Tindale, Norman 1974, Aboriginal Tribes of Australia: Their Terrain, Environmental Controls, Distribution, Limits and Proper Names, Australian National University Press, Canberra.

- 1976, 'Some ecological bases for Australian tribal boundaries', in Tribes and Boundaries in Australia, Nicolas Peterson (ed), Social Anthropology series no 10, Australian Institute of Aboriginal Studies, Canberra: 12-29.

Tonkinson, Robert 1999, 'The pragmatics and politics of Aboriginal tradition and identity in Australia', Journal de la Société des Océanistes 109(2): 133-147.

Veth, Peter 1987, 'Martujarra prehistory: variation in arid zone adaptations', Australian Archaeology 25: 102-111.

- 1989, 'Islands in the interior: a model for the colonization of Australia's arid zone', Archaeology in Oceania 24(3): 81-92.

- 2002, 'Abandonment' or Maintenance of Country? A Critical Examination of Mobility Patterns and Implications for Native Title, Native Title Research Unit, Australian Institute of Aboriginal and Torres Strait Islander Studies, Canberra.

Wells, LA 1893, Journal of the Elder Exploration Expedition, 1891, South Australian Government, South Australia.

White, Isobel 1985, 'Editor's Introduction', in The Native Tribes of Western Australia, Isobel White (ed), National Library of Australia, Canberra: 36-37.

Wolfe, Patrick 1991, 'On being woken up: the Dreamtime in anthropology and in Australian settler culture', Comparative Studies in Society and History 33(2): 197-224.

- 1997, 'Should the subaltern dream? Australian Aborigines and the problem of ethnographic ventriloquism', in Cultures of Scholarship, Sarah C Humphreys (ed), University of Michigan Press, Ann Arbor, Michigan: 57-96. 
This text taken from Aboriginal History, Volume 38, edited by Shino Konishi, published 2015 by

ANU Press, The Australian National University, Canberra, Australia. 